\title{
Methodology for evaluation of post-accidental rehabilitation strategies
}

\author{
O.-M. Badie
}

IPSN/DPRE/SERGR/LESTS, BP. 6, 92265 Fontenay-aux-Roses cedex, France

\begin{abstract}
Post-accidental management aims at restoring acceptable life conditions for population on sanitary, social and economic aspects. It is then a matter for an optimisation process in a multicriteria context, which has to combine quantitative parameters as well as qualitative parameters. In order to fit with this problematic, IPSN has developed and applied a methodology to a major accident situation on a reactor. The methodology consists in making a systematic evaluation of indicators in order to provide intercomparing data for many rehabilitation strategies. The methodology relies on four steps: characterisation of the geographic and demographic environment, radiological diagnosis, selection of countermeasures from a well characterised set of techniques, and last, evaluation of the intercomparing factors. For each selected countermeasures, radiological benefit and some incidences have been calculated: duration of realisation of the countermeasure, materials and human means, worker doses, amount and characteristics of generated wastes. In this context, calculations highlighted the importance of extemal exposure in built areas, and consequently the importance of the corresponding countermeasures. This work is a useful contribution to the clarification of the post-accidental rehabilitation problem.
\end{abstract}

\section{INTRODUCTION}

Nuclear accidents can be managed in two stages: an emergency stage, during which urgent decisions aiming at protecting the public have to be taken and a post-accident stage during which acceptable living conditions are restored for those affected. The first stage begins as soon as the accident occurs. It may continue for several days or even several weeks. At this stage, radiological intervention criteria are used to determine which counter-measures should be applied. The second stage may begin in the first few days after the accident and can last from a few months to several years. The rehabilitation actions taken during this stage are aimed at creating a new, sufficiently stable situation, which is accepted by the parties involved. To reach such a situation, various complex choices have to be made on the basis of a wide range of information. Post-accident management consists in optimising a multi-faceted situation where a considerable quantity of data relating to the accident, the environment and the counter-measures adopted has to be brought into play.

In order to provide a way of dealing with this problem, a methodology was developed by IPSN [1]. It is based on the systematic assessment of quantifiable indicators and consists in proposing elements for comparing the various rehabilitation strategies. The methodology has been applied within the "S3" exercise, which simulates a major accident on a PWR.

\section{CHARACTERISATION OF THE ENVIRONMENT}

\subsection{Characteristics of deposits}

The exercise [2] simulates a major accident on a PWR. Seven radionuclides are considered. Given the lack of accuracy associated with deposit measurement, the heterogeneity of the fall-out and calculation uncertainty, it is preferable to establish zones with the same activity level, differing by a factor of around 10. This leads to four different contamination zones (Table 1). In the study, the maximum distance from the facility is fixed to $50 \mathrm{~km}$. The "zone 0 " from 0 to $2 \mathrm{~km}$ is not taken into account. 
Table 1 - Characteristics of activity level (Bq. $\mathrm{m}^{-4}$ ) in contaminated zones (S3 exercise)

\begin{tabular}{|c|c|c|c|c|}
\hline zone & iode 131 & caesium 134 & caesium 137 & strontium 90 \\
\hline Zone 1 (2 to $5 \mathrm{~km})$ & $2,00 \mathrm{E} 6$ & $6,85 \mathrm{E} 6$ & $4,15 \mathrm{E} 6$ & $3,44 \mathrm{E} 5$ \\
\hline zone $2(5$ to $10 \mathrm{~km})$ & $3,80 \mathrm{E} 5$ & $1,26 \mathrm{E} 6$ & $7,65 \mathrm{E} 5$ & $6,33 \mathrm{E} 4$ \\
\hline zone $3(10$ to $30 \mathrm{~km})$ & $1,08 \mathrm{E} 5$ & $3,49 \mathrm{E} 5$ & $2,11 \mathrm{E} 5$ & $1,75 \mathrm{E} 4$ \\
\hline zone $4(30$ to $50 \mathrm{~km})$ & $1,65 \mathrm{E} 4$ & $5,01 \mathrm{E} 4$ & $3,04 \mathrm{E} 4$ & $2,51 \mathrm{E} 3$ \\
\hline
\end{tabular}

\subsection{Geographical characterisation}

In the geographical sense of the term, the environment is broken down into areas and compartments. In our study, the considered areas are the agricultural and the ones. The corresponding surface areas are given in Table 2. Woodland, ponds and major constructions (such as motorway interchanges) are not dealt with here but will be studied at a later stage.

A compartment is a homogeneous entity as regards its characteristics (the zone to which it belongs, its nature and the use it is put to) and its level of contamination. It is a basic entity whose contribution to the overall radiological impact can be assessed, in terms of both dose and activity. A compartment is also defined as a potential elementary target for a counter-measure and in this sense; the definition of a compartment depends to a great extent on the counter-measures available. In the case being studied here, the areas and compartments are defined and characterised according to data provided by the National Geographic Institute, information supplied by the French National Institute for Statistics and Economic Studies (INSEE) and from the French ministry of agriculture. The following compartments are studied: - As far as the "agricultural area" is concerned, the parts of plants which are above ground and can easily be machine-harvested (such as cereals and other large-scale crops, or even plants in fallow areas), vegetables, farmland (making a distinction between "soil in bare fields and meadows" and "soil in cropproducing fields"), vineyards and orchards, milk and derived produce, poultry and eggs and finally, meat, - In the case of urban area, the roofs of private houses, building glass fronts and walls, roads and pavements, parks and finally "trees and bushes".

Table 2 - Surface of considered compartments and population in contaminated zones

\begin{tabular}{|c|c|c|c|c|}
\hline Zones & Total surface area (ha) & $\begin{array}{c}\text { Surface area of } \\
\text { urban zones (ha) }\end{array}$ & $\begin{array}{c}\text { Surface area of } \\
\text { agricultural } \\
\text { zone (ha) }\end{array}$ & Population \\
\hline Zone 1 & 1650 & 80 & 1450 & 3700 \\
\hline Zone 2 & 5900 & 320 & 4300 & 9000 \\
\hline Zone 3 & 63000 & 3200 & 38000 & 96000 \\
\hline Zone 4 & 126000 & 6500 & 91000 & 62000 \\
\hline
\end{tabular}

\subsection{Demographic characterisation}

In order to assess the contribution of each compartment to the dose received by the public, the interactions between the public and the compartments have to be characterised. These interactions reflect the time spent in the compartments or groups of compartments leading to external and internal exposure through the inhalation and ingestion of dust, food intake and the degree of self-sufficiency in the compartments where there may be internal contamination by ingestion.

The size of the population in each zone is given in Table 2. The typology adopted for determining the critical groups used in the study was obtained by crossing the social and professional categories established in the INSEE statistics [2] as a function of habitat (rural or urban) with the type of dwelling (private house or apartment block) and the breakdown of the French population into age groups [3]. Three groups are presented here as being the most representative of the various exposure configurations (Table 3). 


\section{RADIOLOGICAL CONSEQUENCES WITH NO COUNTER-MEASURE}

\subsection{Dose assessment}

The post-accident radiological impact is assessed by calculating the annual effective dose. By convention, the term "dose" will be used hereafter to mean the annual effective dose. Doses to public are calculated using the ASTRAL [6,7] code for each population group in each of the four contamination zones in question for the seven radionuclides considered. The results presented here do not take into account doses caused by passage of the plume.

The results in Tables 3 and 4 show that external exposure is predominant with the contribution to the total dose in the first year for people living in urban area only with a low self-sufficiency diet. Nevertheless, over time this predominance increases reaching over $65 \%$ in the second year, regardless of the group being considered. In all cases, inhalation is a negligible exposure pathway.

Table 3 - Relative contributions of different exposure pathways to total dose one year after the accident

\begin{tabular}{|l|c|l|l|}
\hline & Adult farm worker & \multicolumn{1}{|c|}{$\begin{array}{c}\text { Adult in urban milieu } \\
\text { Private house }\end{array}$} & $\begin{array}{c}\text { Child in rural milieu } \\
\text { Private house }\end{array}$ \\
\hline Annual dose (mSv) & 346 & 154 & 317 \\
\hline $\begin{array}{l}\text { Contribution of exposure } \\
\text { pathways to total dose }\end{array}$ & $\begin{array}{l}\text { Exp. Ext.: } 32 \% \\
\text { Ingestion: } 68 \% \\
\text { Inhalation: }<1 \%\end{array}$ & $\begin{array}{l}\text { Exp. Ext.: } 68 \% \\
\text { Ingestion: } 32 \% \\
\text { Inhalation: }<1 \%\end{array}$ & $\begin{array}{l}\text { Exp. Ext.: } 33 \% \\
\text { Ingestion: } 67 \% \\
\text { Inhalation: }<1 \%\end{array}$ \\
\hline
\end{tabular}

Table 4 - Relative contributions of different exposure pathways to total dose two years after the accident

\begin{tabular}{|l|l|l|l|}
\hline & Adult farm worker & $\begin{array}{c}\text { Adult in urban milieu } \\
\text { Private house }\end{array}$ & \multicolumn{1}{|c|}{$\begin{array}{c}\text { Child in rural milieu } \\
\text { Private house }\end{array}$} \\
\hline Annual dose (mSv) & \multicolumn{1}{|c|}{114} & 79 & 98 \\
\hline $\begin{array}{l}\text { Contribution of exposure } \\
\text { pathways to total dose }\end{array}$ & $\begin{array}{l}\text { Exp. Ext:: } 65 \% \\
\text { Ingestion: } 35 \% \\
\text { Inhalation: }<1 \%\end{array}$ & $\begin{array}{l}\text { Exp. Ext.: } 88 \% \\
\text { Ingestion: } 12 \% \\
\text { Inhalation: }<1 \%\end{array}$ & $\begin{array}{l}\text { Exp. Ext.: } 71 \% \\
\text { Ingestion: } 29 \% \\
\text { Inhalation: }<1 \%\end{array}$ \\
\hline
\end{tabular}

3.2 Activity per unit mass of certain foodstuffs

Calculation of the activities per unit mass of each radionuclide in the compartments relating to foodstuffs completes the dose assessments. Given the assumptions used in this study, in the first year, the concentration limits authorised for the commercialisation of foodstuffs are exceeded for all produces taken as coming from the four zones (Table 5). The limits are exceeded until the second year in zone 1 for the butchermeat and poultry \& eggs.

Table 5 - Maximum concentrations $(\mathrm{Bq} / \mathrm{kg}$ and $\mathrm{Bq} / \mathrm{l})$ in different foodstuffs - example of ${ }^{[34} \mathrm{Cs}$ and ${ }^{[37} \mathrm{Cs}$ in Zone 1 , the commercialisation limits are given into brackets -

\begin{tabular}{|c|c|c|c|c|c|}
\hline Year & Vegetables & Cereals & $\begin{array}{l}\text { Milk derived } \\
\text { produce }\end{array}$ & Butchermeat & $\begin{array}{l}\text { Poultry } \\
\text { Eggs }\end{array}$ \\
\hline $\begin{array}{c}1 \\
\text { (Commercialisation } \\
\text { standards) }\end{array}$ & $\begin{array}{r}5400000 \\
(1250)\end{array}$ & $\begin{array}{c}59000 \\
(1250)\end{array}$ & $\begin{array}{r}1100000 \\
(1000)\end{array}$ & $\begin{array}{r}6100000 \\
(1250)\end{array}$ & $\begin{array}{r}77000 \\
(1250)\end{array}$ \\
\hline 2 & 600 & 120 & 1350 & 290000 & 71000 \\
\hline 3 & 2450 & 90 & 130 & 2000 & 80 \\
\hline
\end{tabular}

\section{EVALUATING STRATEGIES}

Assessment of the effectiveness of a strategy consists in calculating the advantages and disadvantages of applying a set of counter-measures. The selected indicators must be accessible and representative of the strategies. In this application, the advantages of the strategies are the reduced doses to the population 
groups and the disadvantages are the doses to those applying the counter-measures, the time necessary to implement the strategies and the human and materials resources required.

\subsection{Selecting counter-measures}

Since a great variety of counter-measures are available, a preliminary selection was made on the basis of studies carried out in relation to the Chernobyl accident $[4,5]$. Those still at the development stage and those, which seemed ill suited to large-scale application were eliminated. Table 6 lists the types of counter-measures taken into account and the target compartments to which they correspond. Each type of counter-measure can correspond to a set of techniques implemented in different ways. Soil and meadows, for example, can be cleared using bulldozers, excavators or graders.

Table 6 - List of counter-measures studied

\begin{tabular}{|l|l|l|}
\hline Milieu & Compartment & Types of counter-measure \\
\hline Agricultural & Fields/meadows & Ploughing, stripping \\
\cline { 2 - 3 } & Mass-produced crops and cereals (soils) & Ploughing, stripping \\
\cline { 2 - 3 } & $\begin{array}{l}\text { Mass-produced crops and cereals } \\
\text { (vegetation) }\end{array}$ & Harvesting, pulling up (by bulldozer) \\
\hline Urban & Roads and pavements & Washing \\
\cline { 2 - 3 } & Façades (walls and glass fronts) & Washing \\
\cline { 2 - 3 } & Roofs of houses (sloping) & Washing, roof replacement \\
\cline { 2 - 3 } & Soil in parks & Stripping \\
\hline & Trees and bushes & Pruning \\
\hline
\end{tabular}

\subsection{Implementing strategies}

Two strategies are built. They both rely on:

An interdiction of consumption of contaminated foodstuff the first year after the accident.

A set of actions in agricultural area:

- Harvesting actions, in the case of a farmland covered with vegetal at the time of deposit. This action leads to reduction of the contamination of the soil by a factor of 5 .

- Ploughing agricultural bare soil or soil with little vegetation. This action reduces the concentrations of activity in vegetals by anything up to a factor of 2 ; consequently, milk and meat are similarly affected.

- Stripping and ploughing meadows. This action reduces the concentrations of activity in foodstuffs by a factor of 10. For external exposure, it also reduces the dose due to the compartment by a factor of 10. A set of actions in urban area:

- Washing of roofs, streets, pavement, wall and windows. Washing is an effective counter-measure, especially if it is implemented early after the deposit. The dose due to the compartment affected by washing is reduced by a factor of 1.5 up to 2 , to1.5,

- Pruning of trees, which leads to a reduction of the dose due to the trees compartment, by a factor of

- Stripping of kitchen gardens, which as in agricultural area, reduces the concentrations of activity in foodstuffs by a factor of 10 . This action also reduces the dose due to the compartment by a factor of 10 .

The differences between S1 and S2 rely on the successive washings in S1 (only one in S2), and also on the replacing of the roofs of private houses in $\mathrm{S} 2$.

The effects assessed are expressed in terms of doses to response workers, calculated with the Microshield codes [8], response durations and the human and materials resources required. Other parameters, such as social, economic and psycho-sociological aspects or the side effects of counter-measures, are not studied in this paper. 
The first hypothesis used in this study is that the duration of the strategies should not last more than one year, or 2000 working hours. Beyond this period, additional teams are called in to rescue. A second hypothesis is that the dose to the workers should not exceed $50 \mathrm{mSv}$. Beyond this value, additional teams are also called to help. The results obtained therefore correspond to the implementation of a minimum amount of resources to complete the counter-measures within one year. The advantages and disadvantages of the two strategies are given in Table 7. This table can be considered as a framework for the decision support sheets, which will be provided to the decision-makers.

Table 7 - Comparison of two strategies zones 1 and 4, first year.

\begin{tabular}{|c|c|c|c|c|}
\hline & \multirow{2}{*}{\multicolumn{2}{|c|}{$\begin{array}{l}\text { Strategy S1 } \\
\text { te washing followed by two others } \\
\text { successive washing }\end{array}$}} & \multicolumn{2}{|c|}{ Strategy S2, $x_{x}=-2$} \\
\hline $\begin{array}{l}\text { Roads/pavements/walls } \\
\text { - windows }\end{array}$ & & & One imme & ate washing \\
\hline Parks/stadium & \multicolumn{4}{|c|}{ Stripping } \\
\hline Trees & \multicolumn{4}{|c|}{ Pruning } \\
\hline Roofs & \multicolumn{2}{|c|}{$\begin{array}{l}\text { One immediate washing followed by two others } \\
\text { successive washing }\end{array}$} & \multicolumn{2}{|c|}{ One immediate washing and replacing } \\
\hline Meadows & \multicolumn{4}{|c|}{ Stripping and ploughing } \\
\hline Cereals & \multicolumn{4}{|c|}{ Ensilage and ploughing } \\
\hline 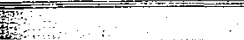 & Zone 1 & Zone 4 & Zone 1 & Zone 4 \\
\hline $\begin{array}{l}\text { Human resources } \\
\text { (urban + agricultural) }\end{array}$ & $26(19+7)$ & $410(286+124)$ & $126(119+7)$ & $2370(2156+124)$ \\
\hline Washing device & 1 & 1 & 1 & 1 \\
\hline Truck-mounted crane & 9 & 131 & 9 & 131 \\
\hline Scaffolding & 0 & 0 & 50 & 930 \\
\hline $\begin{array}{c}\text { Bulldozer } \\
\text { (Urban + agricultural) }\end{array}$ & $4(1+3)$ & $98(22+76)$ & $4(1+3)$ & $98(22+76)$ \\
\hline Transport truck & 16 & 1148 & 120 & 3000 \\
\hline Ensilage machine & 1 & 11 & 1 & 11 \\
\hline Tractor + ploughshare & 3 & 37 & 3 & 37 \\
\hline $\begin{array}{l}\text { Dose to those involved } \\
\text { (mSv) }\end{array}$ & 50 & 1,6 max. (Pruning) & 50 & 1,6 max. (Pruning) \\
\hline $\begin{array}{l}\text { Max. Completion time } \\
\text { (h) (urban, agricultural) }\end{array}$ & $\begin{array}{c}1450 \\
(530,1450)\end{array}$ & $\begin{array}{c}2000 \\
(2000,2000)\end{array}$ & $\begin{array}{c}2000 \\
(2000,1450)\end{array}$ & $\begin{array}{c}2000 \\
(2000,2000)\end{array}$ \\
\hline $\begin{array}{c}\text { Waste (t) } \\
\text { Vegetal } \\
\text { (Urban + agricultural) } \\
\text { Mineral } \\
\text { (Urban + agricultural) }\end{array}$ & $\begin{array}{c}63000 \\
(3000+60000) \\
205000 \\
(23000+182000) \\
\end{array}$ & $\begin{array}{c}3560000 \\
(260000+3300000) \\
8100000 \\
(1800000+6300000)\end{array}$ & $\begin{array}{c}63000 \\
(3000+60000) \\
209000 \\
(27000+182000) \\
\end{array}$ & $\begin{array}{c}3560000 \\
(260000+3300000) \\
8200000 \\
(1900000+6300000) \\
\end{array}$ \\
\hline$\frac{\text { Dose to population }}{\text { (mSv) }}$ & & & & \\
\hline $\begin{array}{l}\text { Adult farm worker. } \\
\text { Zone } 1: 270 \text { people } \\
\text { zone } 4: 39000 \text { neonle }\end{array}$ & $\begin{array}{l}\text { Without counter- } \\
\text { measure - } \\
\text { first year: } 346 \\
\text { (second year: } 114 \text { ) }\end{array}$ & $\begin{array}{l}\text { Without counter- } \\
\text { measure - } \\
\text { first year: } 2,54 \\
\text { (second year: } 0,8^{\prime} \text { ) }\end{array}$ & $\begin{array}{l}\text { Without counter- } \\
\text { measure - } \\
\text { first year: } 346 \\
\text { (second year: } 114 \text { ) }\end{array}$ & $\begin{array}{l}\text { Without counter- } \\
\text { measure - } \\
\text { first year: } 2,54 \\
\text { (second year: } 0,8^{\prime} \text { ) }\end{array}$ \\
\hline & $\begin{array}{c}51,8 \\
\text { (second year: 65,9) }\end{array}$ & $\begin{array}{c}0,38 \\
\text { (second year: } 0,48)\end{array}$ & $\begin{array}{c}45,7 \\
\text { (second year: } 61,9\end{array}$ & $\begin{array}{c}0,34 \\
\text { (second year: } 0,45\end{array}$ \\
\hline $\begin{array}{l}\text { Urban adult } \\
\text { Zone 1: } 1500 \text { people } \\
\text { zone 4: } 8000\end{array}$ & $\begin{array}{l}\text { Without counter- } \\
\text { measure - } \\
\text { first year: } 154 \\
\text { (second year: } 78,9)\end{array}$ & $\begin{array}{l}\text { Without counter- } \\
\text { measure - } \\
\text { first year: } 1,13 \\
\text { (second year: } 0,58 \text { ) }\end{array}$ & $\begin{array}{l}\text { Without counter- } \\
\text { measure - } \\
\text { first year: } 154 \\
\text { (second year: } 78,9 \text { ) }\end{array}$ & $\begin{array}{c}\text { Without counter- } \\
\text { measure - } \\
\text { first year: } 1,13 \\
\text { (second year: } 0,58 \text { ) }\end{array}$ \\
\hline & $\begin{array}{c}34,2 \\
\text { (second year 27,9) }\end{array}$ & $\begin{array}{c}0,25 \\
\text { (second year } 0,20)\end{array}$ & $\begin{array}{c}21,0 \\
\text { (second year: } 19,46 \text { ) }\end{array}$ & $\begin{array}{c}0,15 \\
\text { (second year: } 0,19)\end{array}$ \\
\hline
\end{tabular}


Strategies involving removal of contaminated material (soil stripping, roof replacement etc.) generate waste whose management give rise to severe constraints associated with transport operations, processing and disposal. Depending on the nature and quantity of the waste, it may be compacted, stabilised or directly disposed of. Several disposal routes can be envisaged and will be studied at a later stage. In this study, in view of the levels of activity of the waste likely to be generated, direct disposal in a tip for very low-level radioactive waste seems to be the best solution from a radiological point of view, at least where inorganic waste is concerned. Obviously, the industrial feasibility of direct disposal would have to be considered, along with the side effects and the impact on the economy, before this solution was adopted.

The preliminary results confirm that the resources needed, the time taken to apply the counter-measures and waste management may largely offset the advantages of certain counter-measures in terms of radiological advantage, and the side effects of these counter-measures will also have to be considered. For example, instead of roof replacement and stripping, it may be preferable to opt for successive washing and ploughing respectively since both of these seem to be effective, simple operations which can be carried out rapidly.

\section{CONCLUSION}

The methodology developed by IPSN and applied in this study proposes an organised framework based on the systematic comparison of indicators, useful for managing the complexities of rehabilitation. Its main objectives are to make it easier to calculate the effectiveness of the various strategies as they are established and to produce synthetic sheets of the characteristics of each strategy, thereby providing a decision-support tool. Its application underscored several requirements:

- The first is that efforts must be continued to quantify indicators proposed in the context of new countermeasures,

- It would then be worth creating a counter-measure database containing all the characteristics used to calculate these indicators. Indeed, a large amount of data is currently available but it has not been centralised or standardised.

- This database should then be linked to an operating system, which could be used to rapidly analyse several environmental contamination situations by systematically comparing a large number of strategies. - The methodology will have to be perfected by including secondary contamination phenomena resulting from the flow of activity between compartments.

Finally, within the context of the assumptions and situation adopted, the assessments carried out show that external irradiation is the predominant exposure pathway excepted in the first year, for groups of population which are highly self-sufficient. Thus the counter-measures applied to the urban milieu, lead to the highest dose reductions. Finally, waste management, despite the fact that it has only been mentioned on in this study, is a very penalising operation in the case of certain strategies due to the potential quantities of generated waste.

\section{References}

[1] Badie M., Brun-Yaba Ch., Cessac B., Peres J.-M. Méthodologie d'évaluation des stratégies de réhabilitation d'un environnement contaminé suite à un accident - Application à l'exercice Becquerel, IPSN/DPRE/SERGD Report nº.99/13 (1999).

[2] Bertrand M. Consommation et lieux d'achats des produits alimentaires en 1991 - INSEE Results, Consommation-Modes de vie no. 54-55 (1993).

[3] Cessac B. Habitudes alimentaires retenues pour les évaluations post-accidentelles, DPRE/SERGD/LESTS Technical Memorandum 98/14 (1998).

[4] Besnus F., Jouve A., Peres J.M., Santucci P. Réhabilitation de surfaces contaminées à la suite d'un accident nucléaire et gestion des déchets qui en sont issus, IPSN/DPRE Report no. 96/01 (1996). 
[5] CCE International scientific collaboration on the consequences of the Chernobyl accident (1991-95), Experimental Collaboration Project $\mathrm{n}^{\circ} 4$, Strategies of decontamination, Final report EUR 16530 (1996).

[6] Mourlon Ch. Description des fonctions et des paramètres du module de calcul ASTRAL version 1.1, IPSN/DPRE/SERE Report no. 98/033 (1998).

[7] Bernie J.Ch. Manuel utilisateur, ASTRAL version 1.1, IPSN/DPRE/SERE Report no. 98/037 (1998).

[8] MICROSHIELD - "A shielding analysis and gamma exposure estimation code, Version 5,0", Grove Engineering, Rockville, USA (1995). 